\title{
Ekmeklik Buğday Kalite Değerlendirmesinde Miksolab Cihazının Kullanımı
}

\author{
Mehmet ŞAHIN Seydi AYDOĞAN Aysun GÖÇMEN AKÇACIK \\ Sümerya HAMZAOĞLU \\ Bahri Dağdaş Uluslararası Tarımsal Araştırma Enstitüsü, Konya \\ *Sorumlu yazar e-posta (Corresponding author; e-mail): mehmetsahin222@yahoo.com
}

Geliş tarihi (Received): 31.03.2014

Kabul tarihi (Accepted): 08.05.2014

Öz

Bu çalışmada, ekmeklik buğday ıslah materyalinin değerlendirilmesinde miksolab cihazının kullanım uygunluğunu değerlendirmek için 18 adet kışlık buğday hattı ile 7 adet çeşidi materyal olarak kullanılmıştır. Çalışma ile buğday örneklerinin protein içeriği, sertlik, Zeleny sedimantasyon, ekmek hacmi ve ekmek ağırlık analizleri yanında buğday unlarının reolojik özellikleri miksolab cihazı ile test edilmiştir. Buğday genotiplerinin bazı kalite özellikleri arasındaki ilişkiler miksolab cihazı ile incelenmiştir. Elde edilen sonuçlar göre miksolab değerleri ile buğday genotip özellikleri arasında ilişkilerden C1 değeri ile protein oranı ve Zeleny sedimantasyon, C2 değeri ile sertlik ( $p<0.05)$, C4 ile protein oranı ve Zeleny sedimantasyon arasında negatif ve önemli $(P<0.05), C 1-C 2$ ile protein oranı, Zeleny sedimantasyon, sertlik ve ekmek ağırlığı arasında negatif ve önemli, beta açısı ile protein oranı ve sertlik arasındaki ilişkiler de önemli bulunmuştur $(P<0.05)$. Ekmeklik buğday ıslah materyalinin kalite özelliklerinin değerlendirilmesinde (protein kalitesi, enzimatik aktivite, nişasta retrogradasyonu vb.) miksolab'ın uygun bir cihaz olduğu kanaatine varılmıştır.

Anahtar Kelimeler: Ekmeklik buğday, Miksolab, protein, ekmek hacmi

\section{Utilization of Mixolab in Bread Wheat Quality Evaluation}

\begin{abstract}
In this study, 7 varieties and 18 line winter wheat were used to examine the appropriateness of mixolab device for the evaluation of bread wheat breeding materials. Within this work, protein content, hardness, Zeleny sedimentation, bread volume and bread weight analysis of the wheat samples, in beside of the rheological properties of wheat flour were tested by mixolab device. The relationship between some quality characteristics of wheat genotypes were investigated by mixolab device. According to the obtained results by the mixolab values and wheat genotype characteristics; relationship between the $\mathrm{C} 1$ value and protein content and Zeleny sedimentation, the $\mathrm{C} 2$ value and hardness, the C4 protein content and Zeleny sedimentation negative and significantly important $(P<0.05)$; The relationships between $\mathrm{C} 1-\mathrm{C} 2$ and protein content, Zeleny sedimentation, hardness and bread weight negative and significantly important and beta angle with protein content and hardness were also significant $(P<0.05)$. It was concluded that miksolab is a suitable device for the evaluation of quality characteristics of (as quality protein, enzymatic activity, starch retrogradation, etc.) bread wheat breeding materials.
\end{abstract}

Keywords: Bread wheat, Mixolab, protein, bread volume

\section{Giriş}

$\mathrm{B}$ uğday unu sahip olduğu gluten matriksi ve nişasta granüllerinden kaynaklanan doğrusal olmayan viskoelastiki davranış göstermektedir (Edwards et al. 2002).Buğday unu, hamur oluşturulurken reolojik davranışlar göstermektedir. Bu nedenle hamurun doğru bir karakterizasyonu için elastikiyet, viskozite, uzayabilme gibi reolojik parametrelerin tahminlenmesi gerekmektedir (Banu et al. 2011). Hamurun yoğurma özelliklerinin belirlenmesinde farinograf ve miksograf cihazları kullanılmaktadır.
Hamurun elastikiyet özellikleri, kuvvet ve deformasyon arasındaki ilişki ekstensograf ve alveograf kullanımı ile, ayrıca unun jel, yapışkanlık ve viskozite özellikleri amilograf ve düşme sayısı gibi yöntemlerle ölçülmektedir.

Miksolab 2005'li yıllarda geliştirilmiş yeni nesil bir cihazdır. Miksolab hamuru iki kol arasında yoğurarak çift karıştırma yapmakta aynı zamanda sıcaklık değişimine tabi tutarak hamurun kollara gösterdiği tork'u (Nm) ölçmektedir (Rosell et al. 2007; Kahraman et al. 2008; Öztürk et al. 2008). 
Miksolab cihazının bize sağladığı parametreler şu şekilde özetlenebilir:

1- Protein kalitesi; su kaldırma, stabilite, elastiklik ve zayıflama özellikleri

2- Jelleştirme ve retrogratasyon süresince nişasta davranışı

3- Proteazlar, amilazlar gibi katkı maddeleri katıldığı zaman hamur kıvamı

4- Unun enzimatik aktivitesi hakkında miksolab cihazı bilgi vermektedir (Kahraman et al. 2008; Collar et al. 2007)

Buğday ununun son kullanımında, farklı kullanım alanlarına uygunluğunun belirlenmesi için sınırlı sayıda yöntem vardır (Angioloni and Collar 2009). Ekmekte kullanılan katkı maddelerinin ekmek yapımının değişik aşamalarında hamurun yoğurma özelliklerine ve pişme kalitesine etkilerini incelemede miksolab kullanılmaktadır (Abdel et al. 2009; Huang et al. 2010).

Bu çalışmada ekmeklik buğday kalite ıslah çalışmalarında miksolab cihazından elde edilen parametrelerin diğer bazı kalite özellikleri ile değerlendirilmesi ve aralarındaki korelasyon incelenmiştir.

\section{Materyal ve Yöntem}

Materyal olarak 2013 yılı yetiştirme döneminde yetiştirilen kuru ekmeklik buğday bölge verim denemesinde yer alan 7 ekmeklik buğday çeşidi ve 18 ileri çıkmış hat materyal olarak kullanılmıştır. Deneme materyali Aksaray Koçaş tarım işletmelerinde ekilmiş ve hasat edilmiştir.
Protein miktarı, AACC 39-10 (Anonim 1990) metoduna göre, sertlik (Particle size index) ve kuru gluten Near infrared reflektans spektroskopi (NIR) cihazı ile analiz edilmiştir. Zeleny sedimantasyon ICC-116 (Anonim 1981)'e göre analiz edilmiştir. Buğday örnekleri AACC metod 26-95'e göre \% 14.5 rutubet esasına göre tavlanarak Brabender Junior marka değirmende 6xx elek kullanılarak öğütülmüş olup elde edilen unlarda reolojik analizler yapılmıştır. Ekmek pişirme denemeleri, katkısız direkt hamur işlemini esas alan (AACC-10/10) ekmek pişirme metodu modifiye edilerek kullanılmıştır (Elgün ve ark. 2001). 100 gram una $\% 2$ maya, \% 1.5 rafine tuz ve farinografta kaldırdığı suyun $\% 2$ fazlası verilerek hamur olgunlaşıncaya kadar yoğrulmuştur. Her bir hamur fermantasyon kaplarına konularak \%70 nispi rutubetteki fermantasyon dolabında $30{ }^{\circ} \mathrm{C}$ 'de 30 dakika dinlendirilip havalandırımıştır. İkinci kez 30 dakikalık fermantasyon sonunda şekil verilip ekmek pişirme kaplarına konulmuştur. Son olarak 55 dakikalık fermantasyondan sonra 230 ' $\mathrm{C}$ ' deki taş tabanlı pişirme fırınında 25 dakika pişirilmiştir. Ekmek hacmi ise içinde sorgum tohumu bulunan ekmek hacmi ölçme cihazı ile yer değiştirme metoduna göre saptanmıştır. Ekmek ağırlığı ve ekmek hacmi fırından çıkışta 6 saat sonra ölçülmüştür.

Miksolab cihazı (Chopin Technologies, Villaneuve La Granne, France) ve Chopin protokol+ programı kullanılmıştır. Bu protokole göre un $30^{\circ} \mathrm{C}$ ' de 8 dakika, $90{ }^{\circ} \mathrm{C}$ ' ye kadar ısıtma yaklaşık 15 dakika, $90^{\circ} \mathrm{C}$ ' de 7 dakika ve $50{ }^{\circ} \mathrm{C}$ ' ye kadar soğutma ve bu dereceden 5 dakika sonra analiz tamamlanmaktadır. Toplamda analiz süresi 45 dakikadır. Bu şartlarda hamurun yoğurma kollarına gösterdiği tork miksolab yazılımı tarafından kaydedilmektedir.

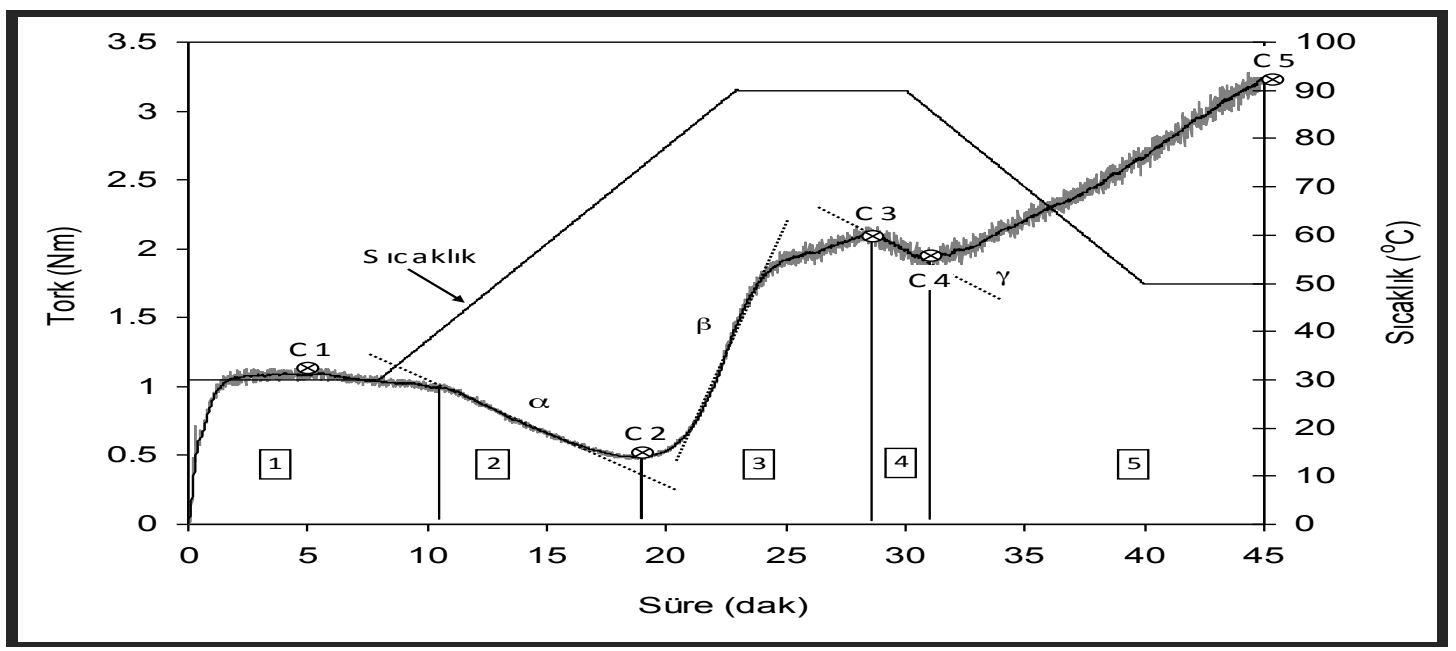

Şekil 1. Ornek Miksolab grafiği

Figure 1. Specimen curve of mixolab 
C1: Birinci bölge hamur sıcaklığının $30^{\circ} \mathrm{C}^{\prime}$ de sabit tutulduğu ve unun su absorbsiyonu, gelişme süresi ve stabilitesi gibi parametrelerin elde edildiği bölgedir. Hamurun stabilitesi ise hamur konsitensinin $1.1 \pm 0.05 \mathrm{Nm}$ üzerinde kaldığı süredir (dak). Hamurun yoğrulmaya karşı davranışı belirlenmektedir.

$\mathrm{C} 2$ : Bu bölgede hamur $60^{\circ} \mathrm{C}$ ' ye kadar ısıtılmaktadır. Hamur sıcaklığının artması ve yoğurmanında etkisiyle hamur konsistensi C2 değerine düşmektedir. C2 fazının başlaması ile bitiş arasındaki fark gluten miktarı ile ilişkilendirilmektedir.

C3: Üçüncü bölgede hamur sıcaklığı $90^{\circ} \mathrm{C}$ ' ye kadar artırılmaktadır. Bu bölgede nişasta jelatinize olmakta ve hamur konsistensi artmaktadır.

C4: Dördüncü bölgede sıcaklık $90^{\circ} \mathrm{C}^{\prime}$ de sabit tutulmaktadır. Burada konsistensin C3' ten C4' e düşmesi nişasta jelinin ısıtılma sırasındaki stabilitesi hakkında fikir verir ve unun amilaz aktivitesi ile de ilişkilendirilmektedir.

C5: Beşinci ve son bölümde ise sıcaklık $90^{\circ} \mathrm{C}^{\prime}$ den $50^{\circ} \mathrm{C}$ ' ye düşürülmektedir. Sıcaklıktaki düşüşle birlikte hamur konsistensi C5' e yükselmektedir. Konsistensin C4' ten C5'e yükselmesi hamurun soğutulması ile birlikte nişastada meydana gelen retrogradasyon ile ilişkilendirilmektedir (Kahraman et al. 2008; Öztürk et al. 2008; Köksel et al. 2009; Dubat 2010).

$\alpha$ açısı: Bu açı ne kadar dikse gluten o kadar zayıf, ne kadar dar ise gluten o kadar kuvvetli olarak adlandırımaktadır.

$\beta$ açısı : Bu açı ne kadar dikse hamur o kadar viskositesi düşük yani hamur sert, tersi durumda ise hamur daha yumuşak akışkan olarak adlandırımaktadır.

y açısı: Amilaz enzim etkisini belirtmektedir.

\section{Bulgular ve Tartışma}

Buğday genotiplerinin kimyasal ve fizikokimyasal analizleri sonucunda protein oranı (\%), sertlik (Particle Size Index (PSI), Zeleny sedimantasyon ( $\mathrm{ml})$, ekmek ağırlığı (g) ve ekmek hacmi (ml) hesaplanmıştır. Genotiplerin ortalama protein oranı \% 12.03 olarak belirlenmiştir (Çizelge 1). En düşük protein oranı \%10.6 ile 17 nolu hatta en yüksek protein oranı ise \% 13.5 ile 11 nolu hatta belirlenmiştir.

Sertlik değeri (PSI) olarak tespit edilmiştir. Buğday genotiplerinin ortalama sertlik değeri 44.5 olarak belirlenmiştir. Sertlik değeri bakımından en sert genotip 30.9 değere sahip 6 nolu hat, en yumuşak genotip ise 65.9 değere sahip 10 nolu hat olmuştur.

Ortalama Zeleny sedimantasyon değeri 29 $(\mathrm{ml})$, en düşük değer 12 nolu genotipte $20(\mathrm{ml})$, en yüksek ise Eraybey ve Tosunbey çeşitlerinde $38(\mathrm{ml})$ belirlenmiştir. Ekmek ağırlığı en yüksek Tosunbey çeşidi ile 23 nolu hatta $142 \mathrm{~g}$, en düşük değer $130.5 \mathrm{~g}$ ağırlıkla 18 nolu hatta belirlenmiş, ortalama ekmek ağırlığı değeri ise $134 \mathrm{~g}$ olmuştur. Ekmek hacmi en yüksek $500 \mathrm{ml}$ ile 10 nolu genotipte, en düşük değer $400 \mathrm{ml}$ ile 6,18 ve 19 nolu genotiplerde belirlenmiştir. Genotiplerin ortalama ekmek hacmi ise $428.8 \mathrm{ml}$ olarak tespit edilmiştir (Çizelge 1). Denemede yer alan genotiplerin miksolab su absorbsiyonu \% 57 ile \%60 arasında değişmiştir. Su absorbsiyonu örneklerin miksolab yoğurma kabında yoğrulurken $1.1 \mathrm{Nm}$ torka ulaşıncaya kadar aldığı su miktarı olarak hesaplanmaktadır. C1 bölgesi değerlendirilirken stabilite ile birlikte değerlendirilmesi daha sağlıklı olacaktır. Şöyleki $1.1 \mathrm{Nm}$ torka ulaşan hamurun bu bölgede zaman açısından uzun süre kalması hamurun konsistensi ve stabilitesi açısından istenen bir durumdur. Bu sürenin uzun olması arzu edilir. Protein yapısı güçlü olan genotiplerde bu sürenin uzun olması beklenir. Bu denemede Bayraktar-2000 çeşidi 8.35 dakika ile en uzun stabilite süresine sahiptir. C1 tork değeri ile protein ve sertlik arasındaki korelasyon ilişkisi önemli $(p<0.05)$, ekmek ağırığı, ekmek hacmi ve Zeleny sedimantasyon testi arasındaki ilişki önemsiz bulunmuştur( $P>0.05)$. Miksolab stabilite değeri ile Zeleny sedimantasyon, ekmek ağırlığı ve ekmek hacmi arasındaki ilişki önemli $(p<0.05)$, protein oranı ve sertlikle olan ilişkinin ise önemsiz olduğu belirlenmiştir ( $P>0.05)$. Öztürk et al. (2008), yaptıkları çalışmada C1 ile protein oranı, miksolab stabilite değeri ile protein ve Zeleny sedimantasyon değeri arasındaki ilişkinin önemli olduğunu belirtmişlerdir. Dhaka et al. (2012), miksolab uygulamaları konusunda yaptıkları çalışmada SDS sedimantasyon testi ile miksolab stabilitesi arasında önemli ilişki olduğunu belirtmişlerdir. 
Çizelge 1. Genotiplerin bazı kalite özellikleri

Table 1. Some quality properties of genotypes

\begin{tabular}{|c|c|c|c|c|c|}
\hline Genotip & PRT (\%) & SRT (PSI) & ZLN (ml) & EAG $(g)$ & $\begin{array}{c}\text { EHCM (ml/100g } \\
\text { un) }\end{array}$ \\
\hline 6 & 11.2 & 30.9 & 21 & 139.1 & 400.0 \\
\hline 7 & 13.1 & 35.0 & 32 & 133.7 & 405.0 \\
\hline 8 & 12.5 & 43.0 & 25 & 131.2 & 450.0 \\
\hline 9 & 11.4 & 34.8 & 26 & 134.3 & 440.0 \\
\hline 10 & 13.2 & 65.9 & 30 & 131.4 & 500.0 \\
\hline 11 & 13.5 & 49.1 & 33 & 135.6 & 425.0 \\
\hline 12 & 11.2 & 51.8 & 20 & 135.3 & 425.0 \\
\hline 13 & 12.6 & 46.9 & 27 & 142.3 & 425.0 \\
\hline 14 & 11.5 & 42.4 & 29 & 136.6 & 430.0 \\
\hline 15 & 11.0 & 46.1 & 29 & 131.9 & 425.0 \\
\hline 16 & 12.6 & 46.0 & 32 & 133.5 & 475.0 \\
\hline 17 & 10.6 & 32.0 & 31 & 130.8 & 430.0 \\
\hline 18 & 11.0 & 42.3 & 22 & 130.5 & 400.0 \\
\hline 19 & 12.1 & 33.7 & 28 & 137.2 & 400.0 \\
\hline 21 & 12.4 & 50.8 & 31 & 138.9 & 415.0 \\
\hline 22 & 12.1 & 35.8 & 27 & 130.7 & 425.0 \\
\hline 23 & 12.5 & 57.6 & 35 & 142.0 & 405.0 \\
\hline 24 & 12.8 & 40.2 & 36 & 127.7 & 415.0 \\
\hline Bayraktar-2000 & 12.6 & 52.0 & 29 & 134.6 & 450.0 \\
\hline Bezostaja-1 & 12.4 & 48.1 & 37 & 131.2 & 450.0 \\
\hline Eraybey & 12.5 & 51.2 & 38 & 135.0 & 415.0 \\
\hline Gerek-79 & 12.5 & 55.3 & 21 & 133.7 & 425.0 \\
\hline Karahan-99 & 12.2 & 53.6 & 29 & 137.5 & 400.0 \\
\hline Müfitbey & 10.7 & 34.3 & 22 & 134.1 & 440.0 \\
\hline Tosunbey & 12.2 & 34.9 & 38 & 142.6 & 450.0 \\
\hline Ortalama & 12.03 & 44.5 & 29 & 134 & 428.8 \\
\hline
\end{tabular}

PRT: Protein miktarı (\%), SRT: Sertlik (Hardness) (PSI), ZLN: Zeleny sedimantasyon (ml), EHCM: Ekmek hacmi (ml/100 g un), EAG: Ekmek ağırlığı (g)

PRT: Protein content (\%), SRT: Hardness (PSI), ZLN: Zeleny sedimentation (ml), EHCM: Bread volume (ml), EAG: Bread weight $(g)$

Miksolab C2 bölgesi sıcaklığın $30^{\circ} \mathrm{C}$ ' den 90 ${ }^{\circ} \mathrm{C}$ 'ye doğru çıktığı bölgedir. Sıcaklığın yükselmesiyle birlikte proteinlerin denatürasyonu başlamakta ve proteinin yoğurma kollarına gösterdiği direnç azalmaktadır (Şekil 1). Miksolab eğrisi aşağıya doğru eğim göstermektedir. C2 tork değeri deneme ortalaması 0.32 olduğu belirlenmiş olup genotiplerin bu bölgede $\mathrm{C} 2$ değerlerinin 0.12 ile $0.59 \mathrm{Nm}$ arasında değer aldığı görülmüştür. 18 nolu genotip en düşük değere sahip olurken Müfitbey çeşidinin en yüksek değere sahip olduğu belirlenmiştir. C2 tork değeri ile diğer özellikler arasındaki ilişki incelendiği zaman protein oranı ile negatif bir ilişki olurken, Zeleny sedimantasyon değeri ile pozitif ve önemsiz, sertlik değeri ile negatif ve önemli ilişki olduğu belirlenmiştir $(p<0.05)$. C2 tork değeri ile ekmek hacmi ve ekmek ağırlığı arasındaki ilişki ise önemsiz bulunmuştur $(p>0.05)$ (Çizelge 3 ). Öztürk et al. (2008), yaptıkları çalışmada C2 tork değeri ile protein oranı ve Zeleny sedimantasyon değeri arasındaki ilişkinin önemsiz olduğunu belirtmişlerdir( $p>0.05)$. Dhaka et al. (2012), miksolab uygulamaları konusunda yaptıkları çalışmada C2 değeri ile protein oranı arasında önemsiz ilişki olduğunu, SDS sedimantasyon testi ile $(p<0.01)$ önemli ilişki olduğunu belirtmişlerdir. $\mathrm{C} 2$ tork değeri ile $\mathrm{C} 1$ tork değeri arasındaki fark incelendiği zaman protein kalitesi hakkında bir bilgi sunduğu görülmektedir.C2-C1 değeri ile protein oranı, sertlik ve Zeleny sedimantasyon arasında negatif ve önemli ilişki olduğu belirlenmiştir $(p<0.05)$.

Üçüncü bölgede nişastanın jelatinize olması ile birlikte hamurun yoğurma kollarına gösterdiği direnç artmakta ve bu dirence göre miksolab grafiği şekillenmektedir. Burada grafik eğiminin dik olması ekmeklik değerlendirmelerinde arzu edilen bir durum olabilir. Eğimin az olması genotiplerin yumuşaklığı ile ilişkilendirilebilir. Bu bölgede sertlik değeri ile ilişkili görülmekle birlikte yani sertlik arttıkça C3 tork değeri artmış olarak görülmektedir (Çizelge 3). Ekmeklik buğday genotiplerinin değerlendirilmesinde yumuşak ürünler veya ekmeklik ürünler konusunda değerlendirme yapma imkanı sunabileceği düşüncesi oluşmaktadır. 
Çizelge 2. Deneme materyaline ait Miksolab analiz değerleri.

Table 2. The values of trial material of the mixolab analysis.

\begin{tabular}{|c|c|c|c|c|c|c|c|c|c|c|}
\hline Genotip & Su ab. & $\mathrm{C} 1$ & Stblt & $\mathrm{C} 2$ & C3 & $\mathrm{C} 4$ & C5 & $\alpha$ & $\beta$ & $y$ \\
\hline 6 & 59.0 & 1.08 & 2.40 & 0.28 & 1.71 & 1.83 & 2.47 & -0.04 & 0.51 & 0.036 \\
\hline 7 & 58.0 & 1.11 & 4.35 & 0.27 & 1.64 & 1.69 & 2.42 & -0.05 & 0.5 & -0.02 \\
\hline 8 & 58.0 & 1.4 & 3.22 & 0.49 & 1.91 & 1.86 & 2.97 & -0.05 & 0.23 & 0.018 \\
\hline 9 & 58.0 & 1.38 & 3.05 & 0.45 & 2.16 & 2.11 & 2.88 & -0.05 & 0.17 & -0.04 \\
\hline 10 & 60.0 & 0.97 & 2.08 & 0.22 & 1.62 & 1.56 & 2.55 & -0.05 & 0.76 & -0.03 \\
\hline 11 & 58.0 & 1.10 & 6.43 & 0.41 & 1.72 & 1.83 & 2.50 & -0.05 & 0.44 & 0.032 \\
\hline 12 & 58.0 & 1.12 & 2.87 & 0.29 & 1.65 & 1.96 & 2.79 & -0.04 & 0.28 & 0.086 \\
\hline 13 & 59.0 & 0.89 & 7.42 & 0.31 & 1.83 & 1.9 & 2.99 & -0.05 & 0.63 & 0.002 \\
\hline 14 & 58.0 & 1.21 & 2.87 & 0.25 & 1.78 & 1.84 & 1.90 & -0.04 & 0.04 & 0.010 \\
\hline 15 & 59.0 & 1.05 & 5.55 & 0.36 & 1.83 & 1.77 & 2.48 & -0.07 & 0.13 & 0.042 \\
\hline 16 & 59.5 & 0.98 & 3.85 & 0.25 & 1.53 & 1.77 & 2.82 & -0.05 & 0.38 & 0.068 \\
\hline 17 & 59.0 & 1.13 & 5.38 & 0.38 & 1.74 & 1.89 & 2.77 & -0.06 & 0.38 & 0.056 \\
\hline 18 & 58.5 & 0.98 & 3.37 & 0.12 & 1.43 & 1.70 & 2.09 & -0.03 & 0.29 & 0.030 \\
\hline 19 & 58.0 & 1.14 & 2.78 & 0.30 & 1.94 & 1.63 & 2.91 & -0.03 & 0.00 & -0.440 \\
\hline 21 & 58.0 & 0.93 & 5.67 & 0.30 & 1.64 & 1.92 & 3.00 & -0.06 & 0.37 & 0.094 \\
\hline 22 & 59.0 & 1.05 & 4.93 & 0.39 & 1.79 & 1.91 & 2.78 & -0.05 & 0.43 & 0.040 \\
\hline 23 & 60.0 & 0.95 & 8.07 & 0.39 & 1.9 & 1.83 & 2.75 & -0.01 & 0.55 & 0.004 \\
\hline 24 & 59.0 & 1.05 & 6.30 & 0.38 & 1.88 & 1.83 & 2.52 & -0.06 & 0.06 & -0.030 \\
\hline Bayraktar-2000 & 57.0 & 0.98 & 8.25 & 0.28 & 1.97 & 1.93 & 3.18 & -0.03 & 0.65 & -0.030 \\
\hline Bezostaja-1 & 59.0 & 1.04 & 5.55 & 0.38 & 1.78 & 1.73 & 2.82 & -0.06 & 0.53 & -0.040 \\
\hline Eraybey & 59.5 & 1.02 & 6.77 & 0.21 & 1.61 & 1.79 & 2.71 & -0.06 & 0.54 & 0.052 \\
\hline Gerek-79 & 58.0 & 0.81 & 1.80 & 0.06 & 1.62 & 1.91 & 2.72 & -0.04 & 0.76 & 0.010 \\
\hline Karahan-99 & 58.0 & 0.91 & 4.95 & 0.28 & 1.92 & 1.77 & 2.96 & -0.07 & 0.11 & -0.110 \\
\hline Müfitbey & 60.0 & 1.53 & 4.07 & 0.59 & 2.02 & 1.99 & 3.09 & -0.06 & 0.02 & -0.010 \\
\hline Tosunbey & 59.0 & 1.06 & 7.95 & 0.43 & 1.81 & 1.94 & 2.78 & -0.04 & 0.48 & 0.024 \\
\hline
\end{tabular}

Su ab.: Su absorbsiyonu (\%), C1: Tork (Nm), Stblt: (stability)(dak) C2: Tork (Nm), C3 : Tork (Nm) C4: Tork (Nm) C5: Tork $(\mathrm{Nm}), \alpha$ : Alfa açısı, $\beta$ : Beta açısı, y: Gama açısı.

Su ab.: Water absorption (\%) C1: Torque (Nm), Stblt: Stability (dak) C2: Torque (Nm), C3: Torque (Nm) C4: Torque (Nm) C5: Torque (Nm), a: Alfa angle, $\beta$ : Beta angle, y: Gama angle.

Çizelge 3. Miksolab ve bazı kalite özellikleri arasındaki korelasyon değerleri Table 3. Values of correlation between mixolab and some quality traits

\begin{tabular}{lccccc}
\hline Özellik & PRT $(\%)$ & SRT $(\mathrm{PSI})$ & ZLN $(\mathrm{ml})$ & EAG $(\mathrm{g})$ & EHCM $(\mathrm{ml})$ \\
\hline Stblt & 0.274 & 0.164 & $\mathbf{0 . 6 6 1 ^ { * }}$ & $\mathbf{0 . 3 3 3 ^ { * }}$ & -0.277 \\
C1trk & $\mathbf{- 0 . 3 6 9 ^ { * }}$ & $\mathbf{- 0 . 5 8 4 ^ { * }}$ & -0.226 & -0.107 & 0.076 \\
C2trk & -0.170 & $\mathbf{- 0 . 3 7 8 ^ { * }}$ & 0.157 & 0.025 & 0.027 \\
C3trk & -0.131 & -0.247 & 0.003 & 0.147 & -0.031 \\
C4trk & $\mathbf{- 0 . 3 2 8 ^ { * }}$ & $\mathbf{- 0 . 3 0 7 ^ { * }}$ & -0.248 & 0.210 & -0.120 \\
C5trk & 0.117 & 0.093 & -0.002 & 0.204 & 0.158 \\
C2-C1 & $\mathbf{- 0 . 4 0 8 ^ { * }}$ & $\mathbf{- 0 . 3 9 1 ^ { * }}$ & $\mathbf{- 0 . 4 8 3 ^ { * }}$ & $\mathbf{- 0 . 3 1 8 ^ { * }}$ & 0.167 \\
Alfa & 0.067 & -0.002 & -0.165 & $\mathbf{0 . 3 7 4 ^ { * }}$ & -0.193 \\
Beta & $\mathbf{0 . 4 8 2 ^ { * }}$ & $\mathbf{0 . 4 3 1 ^ { * }}$ & 0.145 & 0.176 & 0.217 \\
Gama & -0.101 & 0.145 & -0.010 & -0.079 & 0.150 \\
\hline
\end{tabular}

${ }^{*}: p<0.05,{ }^{* *}: p<0.001$ önemli. PRT: Protein miktarı (\%), SRT: Sertlik (PSI), ZLN; Zeleny sedimantasyon (ml), EAGR: Ekmek ağılığı (g), EHCM: Ekmek hacmi (ml).

${ }^{*}: p<0.05,{ }^{* *}: p<0.001$ significant. PRT: Protein content (\%), SRT: Hardness (PSI), ZLN: Zeleny sedimentation (mI), EAGR: Bread weight (g), EHCM: Bread volume (ml). 
Dördüncü bölgede (C4) sıcaklık $90^{\circ} \mathrm{C}^{\prime}$ de sabit tutulmaktadır. Burada konsistensin C3' ten C4' e düşmesi nişasta jelinin ısıtılma sırasındaki stabilitesi hakkında fikir verir ve unun amilaz aktivitesi ile de ilişkilendirilmektedir. Özellikle rutubeti yüksek olan bölgelerde yetiştirilen buğdaylarda kurak bölgelerde yetiştirilen buğdaylara nazaran amilaz enzim aktivitesinin daha yüksek olduğu bilinmektedir. C4 tork değeri enzim hakkında bilgi sunmaktadır. Orta Anadolu gibi kurak bölgelerde yetiştirilen buğday çeşitlerinde enzim aktivitesi daha düşük seyretmektedir. Bu bilgi değirmencilik ve fırıncılık açısından önemli bir bilgidir. Bu çalışmada en yüksek C4 tork değeri $2.11 \mathrm{Nm}$ ile 9 nolu genotipte, en düşük ise $1.70 \mathrm{Nm}$ ile 18 nolu genotipte belirlenmiştir.

Beşinci ve son bölümde ise sıcaklık $90^{\circ} \mathrm{C}^{\prime}$ den $50^{\circ} \mathrm{C}^{\prime}$ ye düşürülmektedir. Sıcaklıktaki düşüşle birlikte hamur konsistensi C5' e yükselmektedir. Konsistensin C4' ten C5'e yükselmesi hamurun soğutulması ile birlikte nişastada meydana gelen retrogradasyon ile ilişkilendirilmektedir. $\mathrm{Bu}$ durum nişasta moleküllerinin soğumasıyla birlikte su moleküllerinin serbest duruma geçmesi demektir. Burada hamurun yoğurma kollarına

Çizelge 4.Deneme materyali Miksolab profil değerler

Table 4. The mixolab profile values of trial material

\begin{tabular}{|c|c|c|c|c|c|c|}
\hline Genotip & Su Abs. & YGR & GLT & VZKS & AMLZ & RTRG \\
\hline 6 & 3 & 3 & 5 & 8 & 8 & 8 \\
\hline 7 & 5 & 1 & 6 & 5 & 9 & 7 \\
\hline 8 & 4 & 2 & 4 & 7 & 8 & 8 \\
\hline 9 & 6 & 4 & 3 & 6 & 9 & 7 \\
\hline 10 & 6 & 2 & 3 & 6 & 8 & 7 \\
\hline 11 & 6 & 1 & 6 & 5 & 8 & 6 \\
\hline 12 & 5 & 2 & 3 & 5 & 7 & 6 \\
\hline 13 & 5 & 1 & 5 & 7 & 8 & 7 \\
\hline 14 & 5 & 1 & 5 & 8 & 8 & 7 \\
\hline 15 & 7 & 1 & 6 & 5 & 8 & 6 \\
\hline 16 & 5 & 2 & 3 & 5 & 8 & 6 \\
\hline 17 & 5 & 1 & 6 & 5 & 9 & 7 \\
\hline 18 & 6 & 4 & 4 & 7 & 8 & 7 \\
\hline 19 & 5 & 4 & 5 & 4 & 5 & 7 \\
\hline 21 & 6 & 2 & 4 & 6 & 8 & 6 \\
\hline 22 & 6 & 1 & 5 & 5 & 8 & 7 \\
\hline 23 & 6 & 2 & 4 & 6 & 8 & 7 \\
\hline 24 & 6 & 2 & 6 & 4 & 8 & 6 \\
\hline Bayraktar-2000 & 5 & 1 & 5 & 7 & 9 & 7 \\
\hline Bezostaja-1 & 6 & 4 & 4 & 5 & 8 & 7 \\
\hline Eraybey & 5 & 3 & 8 & 5 & 9 & 7 \\
\hline Gerek-79 & 6 & 2 & 6 & 6 & 8 & 7 \\
\hline Karahan-99 & 7 & 2 & 3 & 7 & 8 & 7 \\
\hline Müfitbey & 6 & 2 & 3 & 7 & 8 & 5 \\
\hline Tosunbey & 5 & 4 & 6 & 7 & 8 & 8 \\
\hline
\end{tabular}

Su abs.:Su absorbsiyonu, YGR: Yoğurma, GLT: Gluten özelliği, VZKS;Viskozite AMLZ: Amilaz, RTG: Retrogradasyon Su abs.: Water absorption, YGR: Mixing, GLT: Gluten property, VZKS; Viscosity AMLZ: Amylose, RTG: Retrogradasyon gösterdiği dirençte artma meydana gelmekte nişasta sertleşmektedir. Ekmeğin bayatlamasının daha geç olması açısından C5 değerinin düşük olması arzu edilen bir durumdur. Bu çalışmada en yüksek C5 tork değeri $3.09 \mathrm{Nm}$ ile Müfitbey çeşidinde ölçülmüştür. En düşük C5 tork değeride $1.9 \mathrm{Nm}$ ile 14 nolu genotipte belirlenmiştir. Szafranska (2010), yaptığı bir çalışmada en düşük C5 tork değerini $1.42 \mathrm{Nm}$, en yüksek değeri $3.26 \mathrm{Nm}$ olarak belirlemiştir.

Miksolab grafiği ayrıca 3 farklı açı değeri belirtmektedir. Yapılan bu çalışmada alfa açısı en yüksek genotipler Karahan-99 ve 15 nolu genotip olmuş, en düşük değer ise 23 nolu genotipte belirlenmiştir (Çizelge 2). Alfa ve gama açıları ile buğday genotiplerinin protein, sertlik, Zeleny sedimantasyon, ekmek ağırlığı ve ekmek hacmi özellikleri arasındaki ilişki önemsiz bulunmuştur. Beta açısının ise protein ve Zeleny sedimantasyon değeri arasında önemli ilişki olduğu belirlenmiştir $(p<0.05)$ (Çizelge 3 ).

Miksolab cihazının kullanıcılara sunduğu diğer bir özellik profil değerleri ve grafiğidir. Miksolab V3 3.14 versiyonu yazılımı, yapılan analiz sonucuna göre genotiplerin su absorbsiyonu, yoğrulma performansı, gluten kuvveti, amilaz aktivitesi ve nişasta retrogradasyonu hakkında 1 'den 9 kadar 
değişen oranlarda rakamlar vermekte ve bu rakamlarla profil grafiği oluşturmaktadır (Çizelge 4). Ayrıca önceden oluşturulmuş profil grafikleri ile analizi yapılan örneğin profilinin değerlendirilmesinde görsel olarak değerlendirmede kolaylık sağlamaktadır. Yine bu özelliği nedeniyle katkı maddelerinin unun özelliklerine nasıl etki ettiklerini değerlendirme açısından da kolaylık sağlamaktadır. Bu çalışmada profil değerlerinden su kaldırma kapasitesi bakımından, Karahan-99 çeşidi ve 15 nolu genotip en yüksek değere sahip olmuşlardır. Yoğurma özellikleri bakımından Tosunbey, Bezostaja-1, 9, 18 ve 19 nolu genotipler, gluten özelliği bakımından Eraybey çeşidi, viskozite değeri açısından Tosunbey, Karahan-99, Müfitbey, Bayraktar-2000, 13, 18 nolu genotipler, amilaz değeri bakımından Eraybey, Bayraktar$2000, \quad 7,9,17$ nolu genotipler, nişasta retrogradasyonu bakımından Tosunbey, 6 ve 8 nolu genotiplerin en yüksek değere sahip oldukları belirlenmiş̧ir.

\section{Sonuç}

Miksolab cihazı unun hamur oluşturma esnasında sıcaklık değerlerini artırarak ve azaltarak hamurun reolojik özelliklerini ve sıcaklık karşısındaki hareketlerini ölçen yeni nesil bir cihazdır. Bu güne kadar yapılan çalışmalarda (Collar et al. 2007; Kahraman et al. 2008; Banu et al. 2011) ekmek hamurunun reolojik özelliklerinin tespit edilebileceğini belirtmişlerdir.

$\mathrm{Bu}$ çalışmada ölçülen hamur stabilitesi ile protein oranı ve sertlik arasında korelasyonun önemli olduğu belirlenmiştir. Profil değerlendirmeleri gerek sanayici açısından gerekse ıslah materyalinin kalite değerinin ölçülmesi açısından kullanım ve değerlendirme kolaylığı sağlayan bir özellik olarak görülmektedir. Analizi yapılan örneklerin protein kalitesinin yanı sıra nişasta özellikleri hakkında da değerlendirme yapılabilmesi miksolab cihazının olumlu özellikleri olarak görülmektedir.

\section{Kaynaklar}

Abdel-Samie M.A., Wan J.J., Huang W.N., Chung K.O., Xu B.C., 2010.Effects of cumin and ginger as antioxidants on dough mixing properties and cookie quality. Cereal Chem 87: 454-460.

Anonim, 1981. Standard Methods of International Association for Cereal Science and Technology (ICC). Vienna, Austria.

Anonim, 1990. AACC Approved Methods of the American Association of Cereal Chemist, USA.
Angioloni A., Collar C., 2009. Significance of structuring/ prebiotic blends on bread dough thermo-mechanical profile. Eur Food Res Technol. 229: 603-610.

Banu I.,Stoenescu G.,Ionescu V., Aprodu I., 2011. Estimation of the baking quality of wheat flours based on rheological parameters of the Mixolab curve. Czech J. Food Sci. (29) 3544.

Collar C., Bollain C., Rosell C.M., 2007. Rheological behaviour of formulated bread doughs during mixing and heating. Food Science and Technology International, 13:99-107.

Dhaka V., Gulia N., Khatkar B.S., 2012. Application of Mixolab to Assess the Bread Making Quality of Wheat Varieties. 1: 183. doi:10.4172/ scientificreports. 183

Dubat A., 2010. A new AACC international approved method to measure rheological properties of a dough sample. Cereal Foods World (CFW), 55 (3), 150.

Edwards N.M., Dexter J.E., Scanlon M.G., 2002. Starch participation in durum dough linear viscoelastic properties. Cereal Chemistry (79) 850-856.

Elgün, A., Türker, S., Bilgiçli, N. 2001. Tahıl ve Ürünlerinde Analitik Kalite Kontrolü Selçuk Ünv. Gıda Mühendisliği Bölümü Ders Notları. Konya Tic. Borsası Yayın No:2

Huang W.N., Li L.L., Wang F., Wan J.J., Tilley M., 2010. Effect of transglutaminase on rheological and mixolab thermomechanical characteristics of oat dough. Food Chem 121: 934-939.

Kahraman K.,Sakyyan O., Ozturk S., Koksel H.,Sumnu G,Dubat A., 2008.Utilization of Mixolab to predict the suitability of flours in terms of cake quality. European Food Research Technology, 227: 565-570,

Köksel H., Kahraman K.,Sanal T., Sivri Özay D., Dubat A., 2009. Potential utilization of mixolab for quality evaluation of bread wheat genotypes V.86, (5) P. 522 - 526 .

Rosell C.M., Collar C., Haros M., 2007. Assessment of hydrocolloid on the thermomechanical properties of wheat using the mixolab. Food Hydrocolloids, 21:452-462.

Szafranska A., 2010. Prognozowanıe jakoscı makı pszennej na podstawie parametrów oceny jakoscı sruty za pomoca aparatu miksolab. Prace Instytutów i Laboratoriów Badawczych Przemyslu Spozywczego t. 65.

Öztürk S., Kahraman K., Tiftik B.,Köksel, H., 2008. Predicting the cookie quality of flours by using Mixolab. European Food Research Technology, 227:1549-1554 